\title{
THE IMMORTALS OF MELUHA: A STUDY IN GEOPOLITICAL PERSPECTIVE
}

\author{
Dr. Jagdish S. Joshi \\ Mr. Saurabh R. Vaishnav
}

\begin{abstract}
:
Geopolitics is a very sought after research topic these days. It revolves around the political issues related to geography. All the aspects about international politics and foreign policies related to the flora and fauna, mountains, valleys, rivers, demographicsetc. between nations is what geopolitics is all about. The term 'Geopolitics' was originally coined by the Swedish political scientist Rudolf Kjellén. Geopolitics has currently emerged to prominence because of awareness amongst the nations regarding the role that geography plays in forming foreign policies. Be it the collapse of the U.S.S.R. or the emergence of U.S.A. as a superpower after the Second World War, the events do have a connection with Geopolitics.As one of the subthemes of the conference is geopolitical issues in literature, the researcher decided towork in this field.
\end{abstract}

The researcher intends to apply geopolitical issues on a currently famous mythology based novel.The novel is the first book in the Shiva trilogy, The Immortals of Meluha. The primary reason for selecting this novel is that the novel is part of the researcher's $\mathrm{PhD}$ thesis. The Immortals of Meluha is all about the rise of a man from oblivion to stardom. It describes a beautiful journey of a man coming from the wilderness to achieving oneness. It describes a journey of a man destined to be a God whom future generations will be referring as Mahadev or Lord Shiva.The Immortals of Meluha certainly possesses the elements of geopolitics. Shiva is a leader of the Guna tribe in Tibet. But Shiva's land has often been a victim of brutal attacks from Pakratis. The evil intention to misuse the natural resources is what drives the Pakratis to constantly wage attacks on the Guna tribe. Shiva receives an invitation to merge his tribe with the Suryavanshi kingdom, which he accepts. But soon he finds out that the Suryavanshi Empire itself is being devastated by constant terrorist attacks from the 
Towards Excellence: An Indexed, Refereed \& Peer Reviewed Journal of Higher Education

Dr. Jagdish Joshi \& Mr. Saurabh Vaishnav/ Page 79-86

Chandravanshi Empire. And the main element of the conflict is the drying up of Saraswati River which in turn creates havoc in the Chandravanshi Empire.

Hence, in this short overview, we see that major conflicts are taking place because of the over abuse of natural resources, selfish motives to sabotage the natural balance of the land as well as dirty politics being played on the geographic areas. The aim of the researcher is to analyse the novel threadbare with the elements of geopolitical issues.

Key Words: Geography, Politics, Meluha

\section{Introduction:}

Today in an age where 9 countries are capable of bringing devastation to the world by their nuclear force, it seems that we are just sitting ducks on the verge of a catastrophic war. A pile of 16,300 nuclear weapons awaits the orders of a fanatic to send up mushroom clouds high up in air. Interestingly, geopolitics plays a huge role regarding the way political scenarios are played amongst nations. The word geopolitics was originally coined by the Swedish political scientist Rudolf Kjellén. Geopolitics as the name suggests is politics based on geography. It analyses how geographyinfluences power struggle in international relations of countries. Geography has since years been a very important issue for mankind. Several countries are trying to take maximum advantage they can regarding the various parameters of geography.

Both World Wars laid us an example of how emphasis is now more towards geography. Be it climate, topography, flora, fauna, arid and fertile lands, valleys, mountains, deserts or sea. We all know about how Operation Barbarossa during the Second World War (Nazi Germany's operation to take over Soviet Union) failed. Had Russia not encountered one of the worst winters at that time, who knows the condition of the world would have been altered. Gaza Strip is also another important example of geopolitics, where Israelites and Palestinians are constantly in conflict with each other. And should anything be said more about IndiaPakistan conflict regarding Kashmir? There are several examples regarding how important geopolitical scenarios are affecting the nations.

\section{About The Immortals of Meluha:}

The Immortals of Meluha by Amish Tripathi is the first book of the Shiva trilogy that focuses on the making of the legend of lord Shiva. The story unfolds the odyssey of a person called Shiva. He is like a clan leader, a patriarch, to be more specific, who came down from his 
home territory (i.e. somewhere in Tibet) to Meluha (somewhere in Sindh) in search of safety and shelter. Shiva had to abandon his native place as it was frequently attacked by neighboring ethnic groups. The novel starts with Shiva overlooking the landscape and thinking about the ways of protecting his tribe, Guna. He is a brave warrior and protector. $\mathrm{He}$ has battle scars all over his body. The King of Meluha, a powerful empire, Daksha has sent emissary to north India to invite the tribes staying there to come and reside in Meluha. Meluha was created many centuries earlier by Lord Ram, one of the greatest kings that ever lived. However, the once proud empire and its Suryavanshi rulers face severe crisis as its primary river, the revered Saraswati, is slowly drying to extinction. They also face devastating terrorist attacks from the east, the land of the Chandravanshis who have joined forces with the Nagas, a cursed race with physical deformities.

The proposal is accepted by Shiva and him along with his tribe move to Meluha. They reach the city of Srinagar and are received there by Ayurvati, the chief of medicine of the Meluhans. Shiva and his tribe are impressed with the Meluhan way of life. On their first night of stay at Srinagar, the Gunas wake up amid high fever and sweating. The Meluhans, under Ayurvati's orders, carry on the healing process. However, Ayurvati finds out that Shiva is the only one devoid of these symptoms and that his throat has turned blue. This leads the Meluhans to started believing in their fabled savior, Neelkanth.

Shiva is then taken to Devagiri, the capital city of Meluha, where he meets King Daksha. While staying there, Shiva and his comrades, Nandi and Veerbhadra, encounter a beautiful and mysterious woman, who has a look of penance on her face. They later come to know that she is Princess Sati, the daughter of Daksha and is a Vikarma, an untouchable in this life due to sins committed in her previous births. Shiva tries to court her, but she rejects his advances. After various conflicting situations, ultimately Shiva wins her heart and they decide to get married, even though the Vikarma rule prohibits them from doing so. Enraged by the socalled obsolete law, Shiva declares himself as the Neelkanth and swears to dissolve the Vikarma law. Daksha allows Sati to get married to Shiva, amid much joy and happiness.

During his stay in Devagiri, Shiva comes to know of the treacherous wars that the Chandravanshis are carrying on the Meluhans. He also meets Brahaspati, the chief inventor of the Meluhans. Brahaspati invites Shiva and the royal family on an expedition to Mount Mandar, where the legendary Somras is manufactured using the waters of the Saraswati river. Shiva learns that the potion which made his throat turn blue was actually undiluted Somras, 
which can be lethal when taken in its pure form. However, Shiva was unaffected, which was the first sign that he was the Neelkanth. He also learns that Somras was the reason why the Meluhans lived for so many years. Brahaspati and Shiva develop a close friendship and the royal family returns to Devagiri. One morning, the whole of Meluha wakes up to loud noises coming from Mount Mandar. Shiva and his troops reach the hill to find out that a large part of Mandar has been blasted off and many of the inventors killed. There is no sign of Brahaspati, but Shiva finds the insignia of the Nagas, confirming their involvement in the treacherous wars of the Chandravanshis.

Enraged by this, Shiva declares war on the Chandravanshis. With consultation from the Devagiri Chief Minister Kanakhala and the Head of Meluhan Army, Parvateshwar, Shiva advances towards Swadweep, the land of the Chandravanshis. A fierce battle is fought between the Meluhans and the Swadweepans in which the Meluhans prevail. The Chandravanshi king is captured but becomes enraged upon seeing the Neelkanth. The Chandravanshi princess Anandmayi explains that they too had a similar legend that the Neelkanth will come forward to save their land by launching an assault against the 'evil' Suryavanshis.

Hearing this, Shiva is dumbfounded and utterly distressed. With Sati he visits the famous Ram temple of Ayodhya, the capital of Swadweep. There he meets a priest from whom he comes to know about his karma, fate and his choices in life, which would guide him in future. As Shiva comes out of the temple, he notices Sati standing out of the temple waiting for him and a Naga standing near a tree, about to attack Sati. The book ends with Shiva charging to save Sati.

\section{Geopolitical issues in The Immortals of Meluha:}

In the first chapter He has come!, Shiva who is the leader of the Guna tribe, is shown being distressed due to the constant attacks that Pakratis have been launching against his tribe. His tribe is settled at the foot of Mount Kailash in Tibet near MansarovarLake. Shiva's late uncle had tried to make peace with the Pakratis by offering access to the shore to the Pakratis. But the Pakratislust for the prime lands and also full access to Mansarovar made them to attach the Guna tribe again and again. Their selfish motive is what concerns Shiva and he ultimately decides to leave the land and settle in a safer place of Meluha. The first chapter itself shows how geographical locations are the driving force of the policies of the mountain tribes. 
In the first chapter itself, we get to know that Daksha, the Suryavanshi emperor has invited tribes from the Northern India to come and settle in Meluha. It is difficult to comprehend why any emperor would invite foreigners to come and settle in his empire. But after some time it is cleared that the reason why Daksha invited foreign tribes to settle in Meluha is that Meluha lacked population. There was all the arrangements in Meluha but not enough people resided in it. So by inviting foreign tribes, Daksha wanted to increase the population of Meluha, so that ultimately Daksha would be able to get a good number of people recruited in the army to fight war on behalf of Meluha.

In chapter 7, Lord Ram's Unfinished Task, Shiva questions the Suryavanshi emperor, Daksha that how is Somras manufactured? To this Daksha replies that Somras is manufactured at a secret location called Mount Mandar. And one of the chief ingredients in manufacturing Somras is the waters of Saraswati. Daksha mentions that the Chandravanshis had tried to kill the Saraswati to bring harm to the Suryavanshis. To this Shiva questions that how is it possible to kill the river Saraswati. Daksha then enlightens Shiva about the geographical aspect about Saraswati. He mentions that the Saraswati is formed by the confluence of two mighty rivers up north - the Sutlej and the Yamuna. The course of the Sutlej and he Yamuna was considered neutral territory, from which both the Chandravanshis as well as the Suryavanshis drew water for the Somras. Daksha further elaborates that the Chandravanshis diverted the course of Yamuna so that instead of flowing southwards, it started flowing east to meet the main river of the ChandravanshiEmpirei.e. the Ganga.

This led to war where the Suryavanshis attacked Chandravanshis. And ultimately the result was that the Suryavanshis won the war and they restored the Yamuna to her original course which eventually met with the Saraswati. Daksha then alarms Shiva that since the last century, the flow of the Saraswati has been gradually waning. Reading the novel further we will get to know that this is one of the reasons of the Great War happening between the Suryavanshis and the Chandravanshis.

This episode of the novel is a classic example of how water conflicts are taking place in the current times. For example, there has been a constant dispute betweenIndia and Pakistan over the hydro-power on the river Indus. Nations such as China, India, Nepal and Bangladesh are in conflict over the rivers rising from the Himalayas. Not only that but countries like Uzbekistan, Kazakhstan, Kyrgyzstan and Tajikistan are fighting over the waters of Amu Daria and Syr Daria rivers and Aral Sea. Argentina and Uruguay are disputing over the 
Towards Excellence: An Indexed, Refereed \& Peer Reviewed Journal of Higher Education

Dr. Jagdish Joshi \& Mr. Saurabh Vaishnav/ Page 79-86

waters of the river Plate. Also Mexico and United States of America are arguing over the waters of Rio Grande and Colorado. Counties like Palestine and Israel, Iraq and Iran are also engulfed in water conflicts. The Chobe River has caused tension between Botswana, Mozambique, Zambia and Zimbabwe. Not only international policies are affected because of water but talking about India, states such as Tamil Nadu as well as Karnataka are in dispute over the Kaveri River and Andhra Pradesh and Orissa are in dispute over the Vansadhara River.

Also observed in the novel is that in several places, such as Devagiri the capital of Meluha, there are raised platforms being built. These raised platforms signify the difference of classes of the citizens of Meluha. Building houses on raised platforms also gives an added advantage against enemy attacks. The royal family's platform will be different from the rest of the platforms.

In chapter 20 Attack on Mandar, Mount Mandar which houses the facility to produce Somras is attacked and destroyed. Somras is a very important aspect of SuryavanshiEmpire. The Suryavanshis thrive on Somras and their health and age is hugely affected by the consumption of Somras. Somras is the life and soul of every Suryavanshis. A large part of Mount Mandar is missing as it is believed to be bombed by heavy artillery. The description stated about the destruction of Mandar is almost similar to how a place destroyed by heavy artillery will be. Loud noises of bombings are heard, with smoke evidently seen from thousands of milesaway and also quite a structure of Mount Mandar is blown off.

This could be a typical scenario of any heavy artillery ravaged place would be. Attacks such as these to ruin a nation about its main resource are quite common. During a war, the main agenda of enemy nation is to eliminate the main resource of the opposing nation, and bring it down on its knees. The scorched earth policy during the Gulf War of burning down the Kuwaiti oil wells gives a suitable example of how to destroy the main governing resource of a nation and cripple it.

In chapter 23 Dharmayudh, the Holy War, Shiva led the troops of Meluhan army against the Chandravanshis. There is total destruction in the war. Several casualties are reported on both sides, and the Chandravanshis are defeated in the war. The seeds of the war could be seen in the usurpation of the Saraswati waters. The waters of Saraswati have the potency to make Somras. And because of the depletion of its waters, the Suryavanshis think it is the work of 
the Chandravanshis. And ultimately the battle takes place. History has been witness about how many times nations have gone on war because of usurpation of geographical parameters.

\section{Conclusion:}

Thus as observed, the novel The Immortals of Meluhacertainly possesses several geopolitical issues. Be it migrating to a new place, inviting people across to populate the region, building platforms to misuse of water bodies to catastrophic war, all these aspects are governed by the politics based of geographical aspects. During modern times, every nation is more and more focusing on concentrating on the geopolitical issues. Geopolitics is essentially the framework to understand the policies of all nations. Major conflicts are taking place because of the over abuse of natural resources, selfish motives to sabotage the natural balance of the land as well as dirty politics being played on the geographic areas. 


\section{BIBLIOGRAPHY}

Author Amish. N.p., n.d. Web. 10 Sept. 2017.

Hepple, Leslie W. "The Revival of Geopolitics.” Political Geography Quarterly 5.4 (1986):

21-36. Print.

Kliot, Nurit, and David Newman, eds. Geopolitics at the End of the Twentieth Century: The Changing World Political Map. Case Studies in Geopolitics. London: Cass, 2000. Print.

Mamadouh, V. D. "Geopolitics in the Nineties: One Flag, Many Meanings.” GeoJournal 46.4 (1998): 237-253. Print.

Parker, Geoffrey. Geopolitics: Past, Present, and Future. London: Pinter, 1998. Print.

Tripathi, Amish. The Immortals of Meluha. New Delhi: Westland ltd., 2010. Print.

\section{Dr. Jagdish S. Joshi}

Professor-Director

Human Resource Development Centre, Gujarat University, Ahmedabad.

E-Mail id: jisjoshi@ascgujarat.org

Mobile Number: 9426587963

\&

Saurabh R. Vaishnav

Adhyapak Sahayak

St. Xavier's College (Autonomous), Ahmedabad

Postal Address: Plot No. 1657/1, Sector 2/D, Gandhinagar

E-Mail id: saurabh.vaishnav@sxca.edu.in

Mobile Number: 9429027670 